\title{
User satisfaction with complete dentures made by the public network of a city in southern Santa Catarina
}

\author{
Satisfação dos usuários de próteses totais mucossuportadas confeccionadas pela rede pública \\ em cidade sul catarinense
}

Felipe Cechinel VERONEZ'

Fernanda Guglielmi Faustini SÔNEGO²

Renan Antonio CERETTA2

Sonia ZACCARON ${ }^{3}$

Luciane Bisognin CERETTA ${ }^{1}$

\section{ABSTRACT}

\section{Objective}

To assess user satisfaction with complete dentures made and delivered in 2010 by the public health care network of a city in the south of Santa Catarina.

\section{Methods}

This cross-sectional, observational, descriptive study used the Oral Health Impact Profile - 14 questionnaire to collect data. The questionnaire contains 14 questions on functional limitation, psychological discomfort, physical disability, psychological disability, social disability, physical pain, and disability. The survey was done in a city in the south of Santa Catarina. The participants were chosen randomly and kept anonymous. The sample consisted of 247 complete dentures made by the public health network of the city in 2010 for patients aged more than 50 years.

\section{Results}

Based on the social and psychological questions, the upper complete denture have a small effect on the patient's quality of life, while the lower complete denture causes stress, self-consciousness, physical pain, and mastication problems. Therefore, the most severe problems were caused by lower complete dentures.

\section{Conclusion}

Denture follow-up protocols should be created to minimize the damages they cause to patients' health and to reduce treatment loss.

Indexing terms: Complete denture. Health care policy. Oral health.

\section{RESUMO}

\section{Objetivo}

Avaliar a satisfação dos usuários de próteses totais mucossuportadas confeccionadas e entregues no ano de 2010 pela rede publica de saúde do município de uma cidade sul catarinense.

\section{Métodos}

Pesquisa do tipo transversal, observacional, descritiva, a coleta de dados foi realizada através da realização do questionário Oral Health InsuranceProfile - 14, que se constitui de 14 perguntas relacionadas à limitação funcional, desconforto psicológico, inabilidade física, inabilidade psicológica, inabilidade social, dor física e incapacidade. Pesquisa realizada em uma cidade do sul de Santa Catarina, a escolha dos participantes ocorreu de forma randômicae suas identidades foram resguardadas. A amostra composta por 247 próteses totais mucossuportadas confeccionadas na rede publica de saúde no ano de 2010 em pacientes com idade acima de 50 anos.

\section{Resultados}

Pautando nas questões sociais e psicológicas, as próteses totais superiores interferem pouco na qualidade de vida do paciente, enquanto as inferiores conseguem causar um nível de estresse e preocupação, dor física, e problemas na mastigação de alimentos, foram encontrados os resultados mais graves, ressaltando-se nas próteses inferiores.

\section{Conclusão}

Alguns protocolos de acompanhamento após a entrega das próteses devem ser aderidos, minimizando os danos causados a saúde do paciente e diminuir a perda dos tratamentos.

Termos de indexação: Prótese total. Política de saúde. Saúde bucal.

\footnotetext{
${ }^{1}$ Universidade do Extremo Sul Catarinense, Residência em Atenção Básica/Saúde da Família. Av. Universitária, 1105, Universitário, 88806-000,Criciúma, SC, Brasil. Correspondência para / Correspondingauthor: FC VERONEZ. E-mail: <felipecveronez@gmail.com>

${ }^{2}$ Universidade do Extremo Sul Catarinense, Curso de Odontologia. Criciúma, SC, Brasil.

${ }^{3}$ Prefeitura Municipal de Criciúma, Secretaria do Sistema da Saúde, Secretaria de Odontologia. Criciúma, SC, Brasil.
} 


\section{INTRODUCTION}

The National Oral Health Policy - Smiling Brazil (Brasil Sorridente) has been reorganizing actions in the primary health care network, and increasing the number and quality of services by adding oral health teams to the Family Health Care Strategy of the Dentistry Specialization Centers (CEO) and Regional Dental Prosthesis Laboratories (LRPD), as required by the Unified Health Care System principles and guidelines. The LRPD aims to meet the high demand of prosthetic rehabilitations of the Brazilian population because no other health care policy before the Smiling Brazil policy had provided this type of treatment ${ }^{1}$.

Brazil, like other developing countries, has a considerable edentulism rate. According to the first national survey on oral health concluded in March 2004 by the Ministry of Health, $20 \%$ of the Brazilian population is edentulous. Of adults aged 65 to 74 years from the Southern region, 68.20\% use upper complete denture, $39.62 \%$ use lower complete denture, $7.95 \%$ need an upper complete denture, and $14.44 \%$ need a lower complete denture ${ }^{2}$.

A city in the south of Santa Catarina began making complete denturesin June 2010. During this same year, the public health care network made a total of 644 upper and lower complete dentures ${ }^{3}$.

Patient satisfaction with the denture and related functional, biological, psychological, and social aspects require assessment to determine whether oral rehabilitation in a wider context is being achieved.

In this context the general objective of this study was to assess user satisfaction with complete dentures made and fitted by the public health care network of a city in the south of Santa Catarina in 2010, where the study was conducted.

\section{METHODS}

This cross-sectional, observational, descriptive, and quantitative study attempted to quantify the extent to which complete dentures are benefitting the biological, psychological, and social health of the public health care network of a city in the south of Santa Catarina, observing, recording, analyzing, and correlating facts or phenomena without manipulating them. The study was conducted in a city in the south of Santa Catarina. According to the Ministry of health and the demographic census of 2011, the city has 193,989 inhabitants. In 2009 23,595 inhabitants were aged more than 50 years according to the Brazilian Institute of Geography and Statistics ${ }^{4}$.

The participants were chosen randomly. Those who accepted the invitation to participate in the study signed an informed consent form as required by Resolution 196/96 of the National Council of Health, and their identities were kept confidential. The sample consisted of 247 complete dentures made by the public health care network in 2010 in patients aged more than 50 years. The sample included patients with upper and/or lower complete dentures. Sample size was given by the formula proposed by Barbeta ${ }^{5}, \mathrm{n}=\mathrm{N} /\left[(\mathrm{e})^{2} \cdot \mathrm{N}+1\right]$, that is, population size divided by the square of the error (considering an error of 5\%) times population size plus 1; this case includes 644 complete dentures in 2010.

Data were collected by the questionnaire Oral Health Impact Profile (OHIP 14), which consisted of 14 questions related to functional limitation, psychological discomfort, physical disability, psychological disability, social disability, physical pain, and handicap associated with the use of complete dentures. Each question is a fivepoint Likert item with categories $0=$ never; 1 = almost never; 2 = sometimes; 3 = almost always; 4 = always . Some factors investigated by the questions include tasting difficulties, denture-related pain, and denture-related shame, among others.

Once the data were collected, a database was created in the software Statistical Package for the Social Sciences (SPSS) version 18.0, a program that also performs statistical analyses. The software calculated the absolute and relative frequencies of the qualitative variables and stratified the data by dental arch (upper/lower)

The study project was approved by the local Research Ethics Committee under protocol number $88,215 / 2012$

\section{RESULTS}

The study assessed user satisfaction with 71 upper complete dentures and 49 lower complete dentures, totaling 120 complete dentures, made and fitted in 2010 by the public health care network of a city in the south of Santa Catarina, and denture quality.

Of the initial sample of 247 dentures, there was a sampling loss of 127 because it was not possible to contact 124 patients after three attempts, and another three patients died during this period. Table 1 shows the sample characteristics. 
Table 1. Characteristics of the study sample.

\begin{tabular}{|c|c|c|}
\hline Variable & $\begin{array}{l}\text { Upper denture } \\
n=\end{array}$ & $\begin{array}{l}\text { Lower denture } \\
n=\end{array}$ \\
\hline \multicolumn{3}{|c|}{ Uses the denture } \\
\hline $\begin{array}{l}\text { Yes } \\
\text { No }\end{array}$ & $\begin{array}{l}49(69) \\
22(31)\end{array}$ & $\begin{array}{l}18(41.9) \\
25(58.1)\end{array}$ \\
\hline \multicolumn{3}{|c|}{ Has trouble pronouncing words } \\
\hline $\begin{array}{l}\text { Never } \\
\text { Almost never } \\
\text { Sometimes } \\
\text { Almost always } \\
\text { Always }\end{array}$ & $\begin{array}{c}43(87.8) \\
1(2) \\
3(6.1) \\
2(4.1) \\
0(0)\end{array}$ & $\begin{array}{c}15(83.3) \\
0(0) \\
0(0) \\
2(11.1) \\
1(5.6)\end{array}$ \\
\hline \multicolumn{3}{|c|}{$\begin{array}{l}\text { Felt that sense of taste had } \\
\text { worsened }\end{array}$} \\
\hline $\begin{array}{l}\text { Never } \\
\text { Almost never } \\
\text { Sometimes } \\
\text { Almost always } \\
\text { Always }\end{array}$ & $\begin{array}{c}45(91.8) \\
1(2) \\
2(4.1) \\
1(2) \\
0(0)\end{array}$ & $\begin{array}{c}16(88.9) \\
1(5.6) \\
1(5.6) \\
0(0) \\
0(0)\end{array}$ \\
\hline $\begin{array}{l}\text { Had painful ach } \\
\text { Never } \\
\text { Almost never } \\
\text { Sometimes } \\
\text { Almost always } \\
\text { Always }\end{array}$ & $\begin{array}{c}39(79.6) \\
7(14.3) \\
3(6.1) \\
0(0) \\
0(0)\end{array}$ & $\begin{array}{c}10(55.6) \\
1(5.6) \\
4(22.2) \\
1(5.6) \\
2(11.1)\end{array}$ \\
\hline \multicolumn{3}{|c|}{ Was uncomfortable eating foods } \\
\hline $\begin{array}{l}\text { Never } \\
\text { Almost never } \\
\text { Sometimes } \\
\text { Almost always } \\
\text { Always }\end{array}$ & $\begin{array}{c}39(79.6) \\
3(6.1) \\
2(4.1) \\
1(2) \\
4(8.2)\end{array}$ & $\begin{array}{c}10(55.6) \\
2(11.1) \\
1(5.6) \\
1(5.6) \\
4(22.2)\end{array}$ \\
\hline \multicolumn{3}{|c|}{ Has been feeling self-conscious } \\
\hline $\begin{array}{l}\text { Never } \\
\text { Almost never } \\
\text { Sometimes } \\
\text { Almost always } \\
\text { Always }\end{array}$ & $\begin{array}{c}41(83.7) \\
2(4.1) \\
4(8.2) \\
1(2) \\
1(2)\end{array}$ & $\begin{aligned} 12 & (66.7) \\
1 & (5.6) \\
1 & (5.6) \\
2 & (11.1) \\
2 & (11.1)\end{aligned}$ \\
\hline \multicolumn{3}{|l|}{ Has felt tense } \\
\hline $\begin{array}{l}\text { Never } \\
\text { Almost never } \\
\text { Sometimes } \\
\text { Almost always } \\
\text { Always }\end{array}$ & $\begin{array}{c}45(91.8) \\
0(0) \\
2(4.1) \\
2(4.1) \\
0(0)\end{array}$ & $\begin{array}{c}13(72.2) \\
2(11.1) \\
1(5.6) \\
0(0) \\
2(11.1)\end{array}$ \\
\hline \multicolumn{3}{|c|}{ Diet has been unsatisfactory } \\
\hline $\begin{array}{l}\text { Never } \\
\text { Almost never } \\
\text { Sometimes } \\
\text { Almost always } \\
\text { Always }\end{array}$ & $\begin{array}{c}44(89.8) \\
1(2) \\
1(2) \\
1(2) \\
2(4.1)\end{array}$ & $\begin{array}{c}13(72.2) \\
0(0) \\
0(0) \\
3(16.7) \\
2(11.1)\end{array}$ \\
\hline \multicolumn{3}{|c|}{ Has had to interrupt meals } \\
\hline $\begin{array}{l}\text { Never } \\
\text { Almost never } \\
\text { Sometimes } \\
\text { Almost always } \\
\text { Always }\end{array}$ & $\begin{array}{c}46(93.9) \\
1(2) \\
1(2) \\
0(0) \\
1(2)\end{array}$ & $\begin{array}{c}10(55.6) \\
1(5.6) \\
4(22.2) \\
2(11.1) \\
1(5.6)\end{array}$ \\
\hline \multicolumn{3}{|c|}{ Finds it difficult to relax } \\
\hline $\begin{array}{l}\text { Never } \\
\text { Almost never } \\
\text { Sometimes } \\
\text { Almost always } \\
\text { Always }\end{array}$ & $\begin{array}{c}44(89.8) \\
0(0) \\
3(6.1) \\
2(4.1) \\
0(0)\end{array}$ & $\begin{array}{c}14(77.8) \\
0(0) \\
0(0) \\
2(11.1) \\
2(11.1)\end{array}$ \\
\hline
\end{tabular}

Continue.

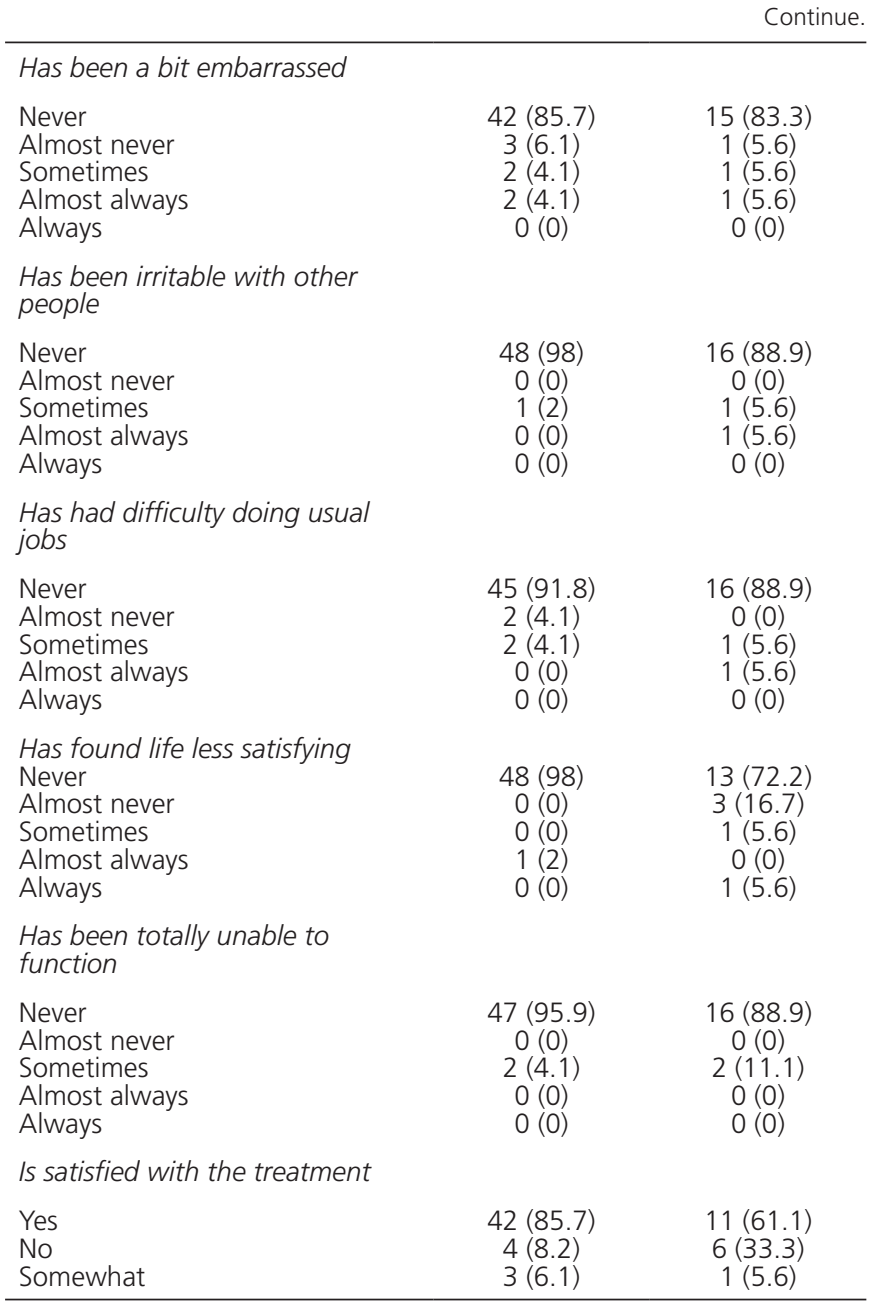

First we assessed whether the patients were using the dentures. Of the dentures fitted during the study period, 49 (69\%) complete dentures were being used by the patients, of which 18 (41.9\%) were lower complete dentures.

Issues that affect eating and oral pain were the most important study findings, especially regarding lower complete dentures. For the question, "Do you have painful aching in mouth?," 39 (79.6\%) of those who were using upper complete denture said they had never felt any aching; of those using lower complete denture, 10 (55.6\%) answered "never," four (22.2\%) answered "almost never," and two (11.1\%) answered "always". For the question on whether eating foods was uncomfortable, $39(79.6 \%)$ of those using upper complete denture said they never experienced any discomfort while eating foods; of those using lower complete denture, 10 (55.6\%) answered "never," four (22.2\%) answered "always," and four $(22.2 \%)$ had to stop eating because of the denture. 
However, the patients felt very little psychological discomfort and disability, especially those wearing upper complete dentures. Only two (11.1\%) patients with lower complete dentures reported "always" feeling tense and self-conscious because of the denture. Forty-two (85.7\%) and 15 (83.3\%) upper and lower complete denture users, respectively, said they "never" had difficulties relaxing because of denture problems. The same number of "never" answers were found for the question, "Have you be embarrassed by problems caused by your teeth, mouth, or denture?"

Milder results were found for questions regarding social disability or deficiency. For the question, "Have you been totally unable to function because of problems with your teeth, mouth, or denture?," 47 (95.9\%) and 16 $(88.9 \%)$ of those who used upper and lower complete denture, respectively, answered "never." Forty-eight (98\%) patients with upper complete denture answered "never" when asked whether they felt life was generally less satisfying because of denture-related problems.

\section{DISCUSSION}

The major concern associated with prosthetic treatments is whether the denture will be used. Considering that quality of life is a multidimensional factor with physical, psychological, and social dimensions, teeth in the oral cavity, even when artificial, provide better phonation, mastication, nutrition, and social interactions ${ }^{6-9}$.

According to the Ministry of Health ${ }^{10}$, the last epidemiological surveys found a high demand for complete dentures given that thirty million Brazilians have no teeth. The resources available for the Unified Health Care System to fabricate of dentures through the federal program Smiling Brazil must be fully used.

Few studies measured this demand, so the literature is scarce for comparing the findings in a country of continental dimension with various social, economic, and educational levels.

The present study found use rates for upper and lower completes dentures of $69 \%$ and $41.9 \%$, respectively.

Some measures to avoid this waste of public resources include decentralization of follow-up with an effective referral and counter-referral system, since the patient is referred to a specialized service, receives treatment, and treatment ends when the denture is fitted. The patient should receive a counter-referral to the dentist who referred him for treatment follow-up. It could be done through active search or by community agents in the first month after the denture is fitted, that is, the functional adaptation period, the most critical period.

Recent studies try to measure not only the clinical quality of the dentures, but also social, behavioral, and psychological aspects of the user ${ }^{11}$. For this purpose, questionnaires such as the OHIP were created, which was used in this study ${ }^{12}$.

The results for "functional limitation," which measures pronunciation trouble and worsened sense of taste, were good: $87.8 \%$ and $83 \%$ of the patients did not experience pronunciation troubles caused by their upper or lower complete dentures, respectively. And the sense of taste did not change for $91.8 \%$ and $88.9 \%$ of those using upper and lower complete dentures, respectively. Although $11.1 \%$ of the patients with lower complete dentures have pronunciation problems "sometimes," this may be attributed to poor denture adaptation because of lack of bone ridges to stabilize the denture. This finding is similar to the $12 \%$ found by Rocha ${ }^{7}$, who also found poor denture adaptation, pointed out that low salivary flow is also a factor that impacts pronunciation, and found that speech difficulty was the reason why $12.86 \%$ of the patients stopped using dentures, an important follow-up factor.

In the category "Pain," the main complaints regarded painful aching in mouth and discomfort eating foods. These were also the most common causes for discontinuing the use of dentures. Of the patients who used upper and lower complete dentures, respectively, $79.6 \%$ and $55.6 \%$ never felt painful aching in mouth; of the lower complete denture users, $22.2 \%$ felt pain almost never and $11.1 \%$ always felt pain. According to Rocha ${ }^{7}$ this pain can be associated with denture retention and stabilization problems, leading to ulcers. However, the number of patients who stoppedusing dentures because of pain was not determined, and for Moreira-da-Silva ${ }^{13}$ this was the main reason for $45.71 \%$ and $58 \%$ of the users to stop using upper and lower complete dentures, respectively.

When asked whether they were uncomfortable eating foods, $79.6 \%$ of the patients with upper complete denture did not feel uncomfortable with anytype of food, while $8.2 \%$ always did. For lower complete dentures, $22.2 \%$ of the patients were always uncomfortable eating foods, and $55.6 \%$ never were. This finding regarding eating discomfort is similar to the $26 \%$ and $24 \%$ found by Maruch $^{6}$ and Rocha ${ }^{7}$, respectively. The absence of chewing efficiency for some foods can lead the patient to prefer softer foods, reducing fiber and nutrient intakes ${ }^{6-7,9}$. 
Most upper complete dentures do not cause psychological discomfort or disability. The higher retention and stability of the upper complete denture may explain the fact that it does not cause irritation, embarrassment, or stress. This finding was also reported by other authors, who suggested that psychological wellbeing is connected to oral health but also depends on other factors ${ }^{7}$. However, the lower complete denture caused self-consciousness. This self-consciousness and/or tension may be related to the patient not feeling comfortable to talk, laugh, or chew, for the lack of retention and instability of the lower complete denture.

Many social, psychological, and biological factors will determine the real needs of a patient, and this will determine his self-perception of health. Thus, many patients, $91.8 \%$ and $88.9 \%$ for the upper and lower complete dentures, respectively, have always been able to function; additionally, $98 \%$ and $72.2 \%$ of patients with upper and lower complete dentures, respectively, never felt life was less satisfying after the denture was fitted. These findings corroborate Rocha ${ }^{7}$, who also found that these dimensions were affected the least.

\section{REFERENCES}

1. Brasil. Ministério da Saúde. Portal Brasil [texto da Internet]. Brasília: Portal Brasil; 2011 [citado 2012 Nov 25]. Disponível em: <http://www.brasil.gov.br/sobre/cidadania/brasil-sem-miseria/ acesso-a-servicos/brasil-sorridente>

2. Brasil. Ministério da Saúde. Secretaria de Atenção à Saúde. Departamento de Atenção Básica. Projeto SB Brasil 2003: condições de saúde bucal da população brasileira 2002-2003: resultados principais. Brasília: Ministério da Saúde; 2004 [citado 2012 Nov 25]. Disponível em: <http://dtr2001.saude.gov.br/ editora/produtos/livros/pdf/05_0053_M.pdf >

3. Criciuma.sc.gov.br [sítio da Internet]. Criciúma: Prefeitura Municipal de Criciúma; 2013 [citado 2013 Mar 19]. Disponível em: <http://www.criciuma.sc.gov.br>.

4. Brasil. Ministério da Saúde. DATASUS: informações de saúde. População residente em Santa Catarina no município de Criciúma. Brasília: Ministério da Saúde; 2010 [citado 2012 Maio 10]. Disponível em: <datasus.gov.br>.

5. Barbetta PA.Estatística aplicada às Ciências Sociais. $5^{a}$ ed. Santa Catarina: Editora UFSC; 2002.

6. MaruchAO, FerreiraEF, VargasAMD, Pedroso MAG, Ribeiro MTF. Impacto da prótese dentária total removível na qualidade de vida de idosos em grupos de convivência de Belo Horizonte MG. Arq Odontol. 2009;45(2):73-80.

7. Rocha RF, Perlin J, Guerino P, Guimarães MB.Impacto do uso de próteses totais na qualidade de vida de idosos. Rev Cont\&Saúde. 2011;10(20):1015-1020.

\section{CONCLUSION}

At the end of the study, all questions were answered. For the social and psychological questions, the upper complete denture has little impact on the patient's quality of life, while the lower complete denture can cause some stress and self-consciousness. For the questions on painful aching in the mouth and discomfort eating foods, the lower complete denture is the most problematic.

Most patients are satisfied with their dentures.

Protocols are needed to reduce treatment loss after the dentures are fitted, especially the lower complete denture.

\section{Collaborators}

FC VERONEZ was responsible for interviewing and collecting patients' data and writing the article. FGF SÔNEGO and RA CERETTA helped to write the article. S ZACCARON found patients with complete dentures in Criciúma and helped to carry out the interviews, collect patients' data, and write the article. LB CERETTA was responsible for the statistical analysis, epidemiological study, and article writing.

8. Papas AS, Palmer CA, Rounds MC, Russell RM. The effects of denture status on nutrition.Spec Care Dentist. 1998;18 (1):17-25.

9. Brodeur JM, Laurin D, Vallee R, Lachapelle D. Nutrient intake and gastrointestinal disorders related to masticatory performance in the edentulous elderly. J ProsthetDent. 1993;70(5):468-73.

10. Brasil. Ministério da Saúde. Portaria n. 1570/GM de 29 de julho de 2004. Estabelece critérios, normas e requisitos para a implantação e credenciamento de Centros de Especialidades Odontológicas e Laboratórios Regionais de Próteses Dentárias [texto na Internet]. Diário Oficial da União; 2004 Jul 30 [citado 2013 Mar 19]. Disponível em: <http://dtr2001.saude.gov.br/sas/ PORTARIAS/Port2004/GM/1570re.htm>.

11. Vecchia MPD, Regis RR, Muglia VA, Souza RF. Qualidade de vida associada à saúde bucal em portadores de próteses totais convencionais e implantorretidas: relato de dois casos. Rev OdontolUNESP. 2009;38(3):198-203.

12. Slade GD, Spencer AJ. Development and evaluation of the Oral Health Impact Profile.CommunityDent Health. 1994;11(1):3-11.

13. Moreira-da-Silva, Santos JEK, Bindo MJF, Leão MP, Costa RG, Morais ECC, et al. Complete dentures in the health public services of Curitiba, Brazil [abstract 1587]. In: IADR Annual Meeting; 2010 July 17-14; Barcelona. 